\title{
Assessing the Spatial-Temporal Land use Change and Encroachment Activities Due to Flood Hazard in North Coast of Central Java, Indonesia
}

\author{
Imam Setyo Hartanto and Rini Rachmawati
}

Received: January 2017/ Accepted: July 2017 / Published online: December 2017

(๑) 2017 Faculty of Geography UGM and The Indonesian Geographers Association

\begin{abstract}
Demak is known as the second largest region suffering land use change in Java's North Coast. The topographic condition in downstream affects this area becomes susceptible with flood hazard. This research aims to assess the interactions between flooding, land use change and encroachment activities in Mijen and Wedung sub districts, Demak region, Central Java, Indonesia. This research combines the Driving Force, Pressure, State, Impact and Response (DPSIR) analysis. The supervised classification by Maximum Likelihood of time series Landsat images (2000, 2009 and 2014) was chosen for land cover analysis. The land use change shows that paddy field area descended almost $6 \%$, mangrove forest fall 79\% meanwhile settlement grown up almost double in 2000-2014. The result of overall accuracy assessment is 78.23\%. The DPSIR result shows that land use change not too affect the flood events but floods influence land use pattern in north and south area of Mijen and Wedung.
\end{abstract}

Key words: Flood, Land Use Change, Encroachment, DPSIR

\begin{abstract}
Abstrak Demak merupakan daerah tertinggi kedua yang mengalami perubahan penggunaan lahan di wilayah Pantai Utara Jawa (PANTURA). Kondisi topografinya yang berada di daerah hilir mengakibatkan daerah ini rawan bencana banjir. Penelitian ini bertujuan untuk menganalisa interaksi antara banjir, perubahan penggunaan lahan dan aktivitas yang mengakibatkan perubahan lahan di kecamatan Mijen dan Wedung, Kabupaten Demak, Jawa Tengah-Indonesia. Penelitian ini menerapkan analisis DPSIR (Penyebab Utama, Tekanan, Keadaan, Akibat dan Respon) guna memahami akar permasalahan dan efek berantai dari hubungan tersebut. Klasifikasi terbimbing dengan Maximum Likelihood dari Citra Landsat (2000, 2009 dan 2014) dipilih untuk pemetaan dan analisis tutupan lahan. Hasil perubahan penggunaan lahan menunjukkan bahwa sawah berkurang 6\%, hutan mangrove terdegradasi sebanyak 79\% sedangkan pemukiman berkembang dua kali lipat selama periode 2000-2014. Hasil analisis akurasi menunjukkan nilai sebesar $78.23 \%$. Hasil analisis DPSIR menunjukkan bahwa perubahan penggunaan lahan tidak terlalu mempengaruhi kejadian banjir tetapi banjir mempengaruhi pola penggunaan lahan di bagian utara dan selatan wilayah Demak.
\end{abstract}

Kata Kunci: Banjir, Perubahan Penggunaan Lahan, Perambahan, DPSIR

\section{Introduction}

The human expansion has changed land-cover and land-use patterns dramatically in global scale [Genxu et al., 2006] . Liu et al., [2014] mentioned that land use changes that were caused by human activities has influenced the characteristics and pattern of flooding or increased the risk of flood for the inner urban human sphere. Encroachment activity is one the result of human expansion from space needed. Greene \& Harlin [1995] stated that in United States (US), urban encroachment on going to consume basis farmland especially on the outskirts of many metropolitan areas. El-Raey et al, [2000] found that most of the encroachment area was changed to be an agricultural and tourist importance.

\footnotetext{
Imam Setyo Hartanto

Teluk Cenderawasih National Park, Ministry of Environment and Forestry, Indonesia

Rini Rachmawati

Department of Development Geography, Faculty of Geography, Universitas Gadjah Mada, Indonesia

Correspondent email: imam.setyo.h@mail.ugm.ac.id
}

Demak regency has known as one of rice barn regionin Indonesia. However the topographiccondition in downstream area and final outflow of several rivers to Java Sea make Demak become susceptible with flood hazard. The two sub districts which are most impacted by flood hazard are Mijen and Wedung [BNPB, 2014]. On the other side, as much as 232 Hectares area in Demak regency affected by land use change in the period 2006 to 2009 [Mustopa, 2011].

It is now well accepted that there exists causal links between environmental degradation, land use and vulnerability to disaster. The increase in population number directly affect to settlement and space area especially land availability. Liu et al. [2014] explain that the growth of human areas has been substantial decreasing the rivers, lakes, forest and grassland. All of this resulting rural area becomes fragile in land use change activities. It was clearly known that agricultural land encroached by rural settlements [Cao et al., 2011]. A general assumption is that land encroachment in floodplain causes more flooding in downstream 
areas. Meanwhile, regularly flooding will affect on development in another area. It is related to effort in avoiding loses which is caused by flooding.

The holistic approach is needed to understand the main problem and find better solution in humanenvironment relationship. The DPSIR framework is an effective approach to organize information of policy making [Agyemang et al., 2007]. Benini et al., [2010] applied a DPSIR-based conceptual framework to describe the effect of the agricultural land use change at Lamone river basin in Northern Italy. Therefore, the study objectives were to (i) determine the current effect of riverine flooding on land use in the study area; (ii) identify the effect of flood hazard on land use change over the period 2000-2014; and (iii) determine the relationship between riverine flooding and land encroachment.

\section{The Methods}

Time series satellite images which are used for this research are: a) Landsat 7 image of 2000; b) Landsat 7 image of 2009; and c) Landsat 8 image of 2014. Meanwhile preliminary historical data flooding was collected from Regional Disaster Management Agency (BPBD) and Water Resources Management Agency (Balai Pengelolaan Sumber Daya Air). Several items of interview guide were also prepared to help the DPSIR approach analysis.

\section{Land Cover-Use Mapping and Analysis}

Land cover map are obtained from interpretation of time series Landsat images 2000, 2009 and 2014. Interpretation of Landsat images are conducted by employing supervised classification [Richards \& Jia, 2006] as the technique most often used for the quantitative analysis of remote sensing image data. The Maximum Likelihood was chosen as supervised classification method for this research. It applied five (5) classes (built up, agriculture, wetland, forest and water body) as representative of land cover in the image.

The land use classification in this study uses the Anderson's classification system [Anderson et al., 1976] that helps to transfer from land cover to land use classes in a structural manner. The Anderson's classification was to be modified to the land cover and land use based on region characteristic in Indonesia especially in Mijen and Wedung sub district. Ding et al., [2007] provide an example modification land use scheme in China whereas in India, Gupta \& Roy [2012] modified Anderson's classification depends upon the available features of Burdwan municipality. A similar approach was applied in this study.

The land use accuracy was assessed by confusion matrix. It is applied by selecting test points (or pixels) and comparing the land cover or land use attribute with the same information from a field survey (ground truth). The result is a matrix where the commission and omission errors also the producer and the user accuracy for each class.

\section{Land Use Change Analysis}

In this research, post-classification change detection technique was applied. Shalaby \& Tateishi [2007] stated that post-classification comparison proved to be the most effective technique. The advantage of this method is not only ascertaining the spatial distribution of changes but also illustrates the nature of changes. In general terms, the transition information from one class to another is well known.

Post classification method is the most simple change detection analysis technique. Cross tabulation of Spatial Analysis Module was applied in this procedure. Each image of multi temporal images was classified separately and then the classification result images were compared each other. If the corresponding pixels have the same category label, the pixel has not changed, or else the pixel has changed. The type of change of each changed pixel is determined in the change detection matrix. A change matrix was constructed for each pair of gridded datasets in land use change quantification [Guo et al., 2009].

\section{Flood Event Monitoring and Analysis}

Flood event data in 2013 and 2014 was collected from Water Resources Management Agency (Balai Pengelolaan Sumber Daya Air) of Kudus report. In addition, interview to local people is applied to get the flood event and depth data around 2000-2014. The aim of interview process is to clarify the previous flood event report. On this stage, three to five (3-5) key informants per village were chosen to understand the flood depth and boundaries.

This interview result was strengthened by flood depth tracing observation data. By looking the print of flood event in cement wall of the interviewee (informant), the measurement of the depth can be applied. If there is no cement wall house, the informant was asked to describe the approximately of the depth flooding with their body such as high as breast or knee etc. This step will produce the flood depth data and description of impacted flood area.

The flood data result was applied by delineating flooded area in spatial analysis process. The flood depth was produced by interpolate the depth value of each ground observation point. Interpolation refers to the process of estimating the unknown data values for specific locations using the unknown data values for other points. The interpolation surfaces in spatial analysis used Inverse Distance Weighted (IDW). The 
IDW applied sample points using a linear-weighted combination set to determines cell values [Childs, 2004]. Those processes were resulted flooded area distribution map and flood depth map.

\section{Determine Encroachment Activities}

Encroachment activity is known by detecting the fault existence feature in space and function of land use/cover change map. Although it cannot generalize the condition in a watershed, at least it will bring a few descriptions about relation between three components (land use, encroachment and flood) in sequential downstream area.

Encroachment in this research defines as conversion of conservation and protection area into built up area and cultivated land. Visual interpretation of land use change maps 2000-2014 is needed to detect encroachment activity. The result of land cover change analysis could be an indicator of encroachment activity. On screen digitizing of encroachment area was applied on this research.

Ground truth by field observation is important to assess the correctness of encroachment feature interpretation. It conducted by taking documentation and direct observation of encroachment feature candidate.

\section{Flood, Encroachment and Land Use Response Analysis}

Qualitative approach by using DPSIR analysis is applied in this section. The first step, the database development is built by selecting a list of indicator for each category of the DPSIR [Pirrone et al., 2005; Secondly, semi-structured interview method with key informant applied to assess DPSIR indicator and gathering additional information [Agyemang et al., 2007]. Third is summarizing and categorizing information from interviews result. The last step is providing a framework for developing models or decision support tools which can be used to evaluate and compare decision outcomes.

Semi-structured interview with key informant is conducted as a tool to collect DPSIR data assessment. The interview questions were tried free flowing and allow the informant to provide their knowledge and expertise on the topic. Eleven (11) key informants were selected including representative from farmers, Head Villages, Chief of Wedung and Mijen Sub District also official representative of Regional Disaster Management Agency. They were chosen based on the knowledge of their society, area representation of each village and direct relation of the disaster management.
The key informants are important respondents to understand about causes-effect of flood, land use change or encroachment activities in different perspectives. The answer of the interview question described their point of view about the main cause of the disaster and how they link the three elements in general. In addition, although the years of land use maps and flood maps used does not match but both are used to describe the trend and development of flood and land use in general for last 15 years.

For the case of vulnerable area for flood, attention should be brought to the utilization of space related to vulnerable groups [Rachmawati \& Budiarti, 2016]. In this research, the vulnerable groups are people who living at the area closest with the flood. So it can be affected area with highest risk.

This research applied triangulation method to assess the validity of interview results. Triangulation reinforce the validity and confident of research results. The secondary data collection from the agencies was triangulated by looking the outcomes that are agreed upon by all stakeholder groups. The weight of evidence suggests that if every stakeholder, who is looking at the issue from different points of view, sees an outcome then it is more than likely to be a true outcome.

\section{Result And Discussion}

\section{Land Cover Map 2000, 2009 and 2014}

This research defined five land cover classes which are: built up, agriculture, wetland, forest and water body. Built up area was grown up respectively each period. Interestingly, they were transformed from the separated location from the first became collected settlement as known as villages/sub-villages. Most of villages/sub-villages located at along sub district bordered. The development of land cover classess in Mijen and Wedung sub districts from 2000 to 2014 are shown in Figure 1, 2 and 3.

The development of built up area happened especially in along region border also on side of Serang and Wulan rivers. It was founded that this development is along with the needed of accessibility especially road. Along region border with Jepara and Kudus district, it was connected with regency main road. Another finding that people who lives at side of Serang and Wulan rivers most of them are farmers. The accessibility of water resources was the main reason of people who lived there. It is primary needed for their living and agricultural plantation. 


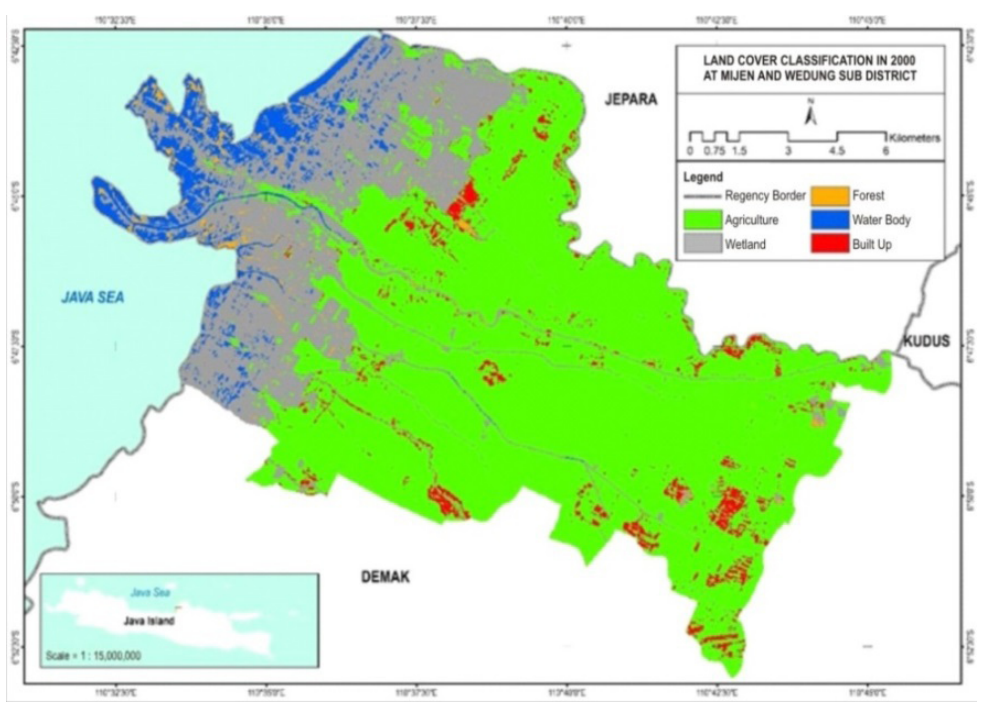

Figure 1. Map of Land Cover at Mijen and Wedung Sub District at 2000.

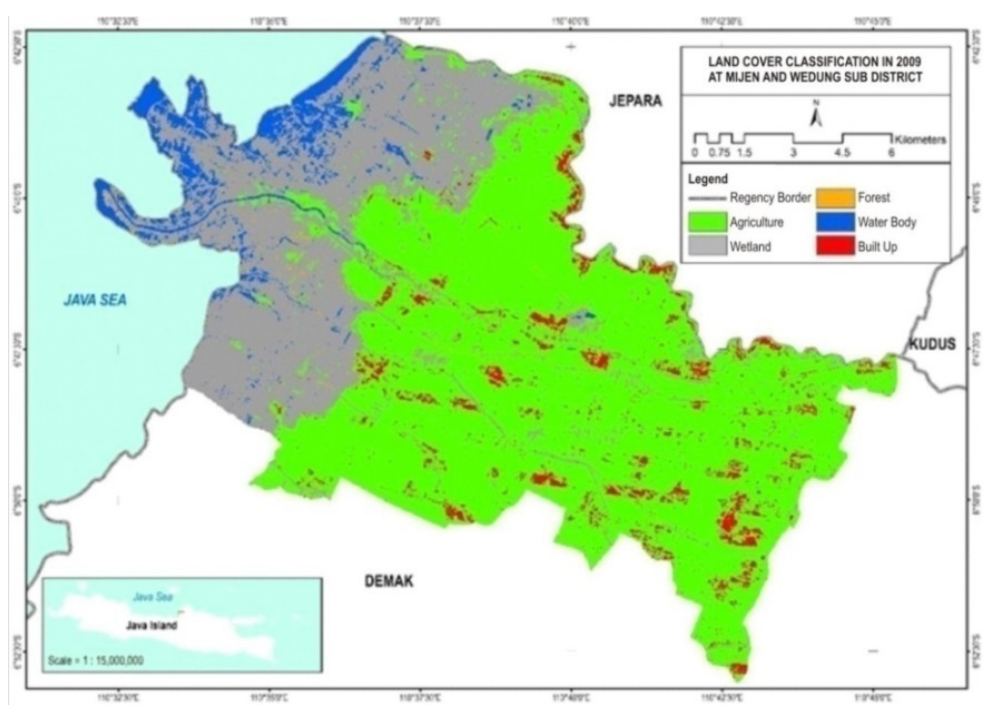

Figure 2. Map of Land Cover at Mijen and Wedung Sub District at 2009.

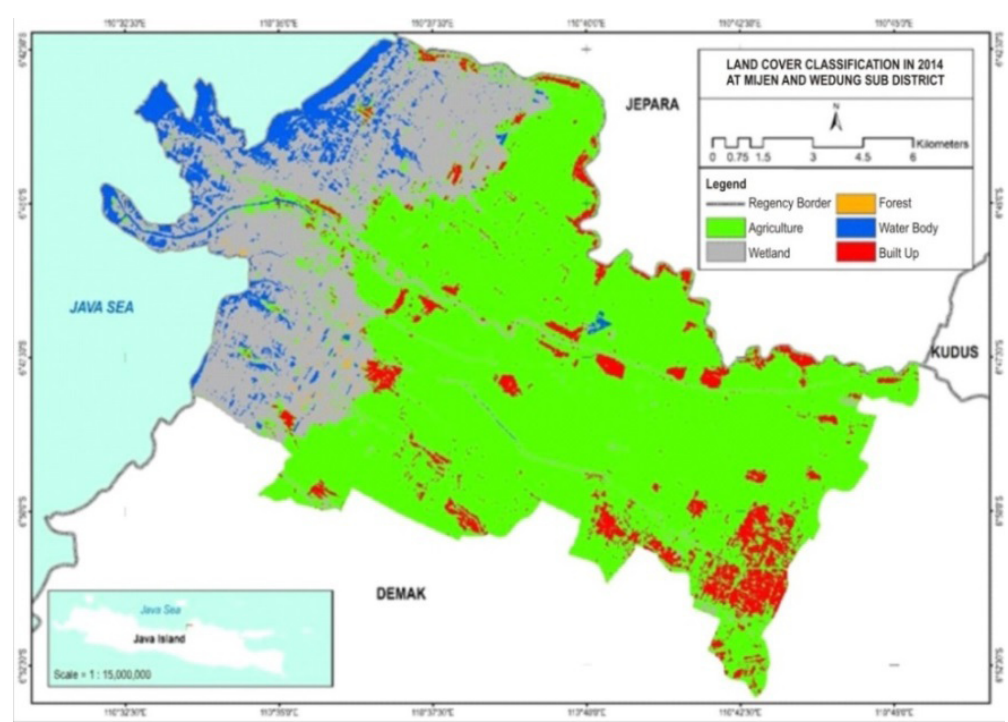

Figure 3. Map of Land Cover at Mijen and Wedung Sub District at 2014. 
Table 1. The Matrix of Land Cover Change from 2000 to 2014

\begin{tabular}{lccccc}
\hline \multirow{2}{*}{ Land Cover } & \multicolumn{3}{c}{ Land Cover (Ha) } & Change (Ha) & \multirow{2}{*}{ Percentage (\%) } \\
\cline { 2 - 5 } & 2000 & 2009 & 2014 & $(2000-2014)$ & \\
\cline { 2 - 5 } Agriculture & 9854 & 9189 & 9304 & -550 & -5.58 \\
Wetland & 3735 & 4402 & 3802 & +67 & +1.79 \\
Forest & 90 & 46 & 19 & -71 & -78.89 \\
Water Body & 732 & 651 & 817 & +85 & +11.61 \\
Built Up & 494 & 618 & 963 & +469 & +94.94 \\
Total & 14905 & 14906 & 14905 & & \\
\hline
\end{tabular}

Unfortunately, the development of built up area in 2009 is not clearly showed. It was caused by poor quality of satellite image, although it is the best image from that period. Several part of the Landsat image in 2009 get refraction and color distortion. The counting of the number and total settlement classes is needed to understand the increasing trend of built up area.

The development of wetland rise significantly. It is known from the three previous maps where map of 2000 shows that the wetland class area is rare in some region and it completed in the next periods (2009 and 2014). Some green area (agriculture) is also changed into wetland in 2009 and 2014 periods.

Meanwhile, forest exists on along north coast of Wedung sub district in map of 2000. The numbers become smaller and almost disappear in 2009 and 2014. It happens because some of them were transformed into wetland (such as ponds) and influenced by tidal flow also wave erosion from Java Sea.

\section{Land Cover Change Analysis}

The land cover change analysis considered pixel calculation for each class. The calculation of land cover changes is done by matrix (pixel) analysis of Maximum Likelihood. The patterns of land cover change over time are presented in table 1 .

Based on the land cover change matrix; it is known that forest and agriculture area decrease over time. Meanwhile, built up area always increase significantly over time. Built up area dramatically transformed almost double from 2000-2014 with annual growth is $6.78 \%$. The smallest changing happened to wetland which is altered $1.79 \%$ in 14 years. Agriculture area descended amount $550 \mathrm{Ha}$ from 2000 to 2014. In line with agriculture, forest falls almost $78 \%$ in along 14 years.

The significant expansion of built up area in a row of population growth at Mijen and Wedung sub district. In addition, area in a long of district road has been developed as administrative and economical region. It attracted people to live there. Several companies were built in those region including concrete brick company, rice mill company, tobacco company, local drink water company and another private company.

The interesting finding is both agriculture and wetland has similar pattern on different trend. From 2000-2009, agriculture area lost around 665 Ha. Just the opposite, wetland class rises in similar number. This condition is supported by the fact that many land owners in Mijen and Wedung sub district changed their land become ponds. Higher cost of agricultural production, dependence of weather condition and lower selling price are the main reason of this trend. They calculated that ponds are more beneficial than agriculture productions.

The calculation of cross tabulation five land cover classes at 2000-2014 was indicated that as much 750 $\mathrm{Ha}$ of agriculture area changes into built up to fulfill human needed of house, office and other commercial building. At the same period, most of forest transforms into wetland and water body. Wave erosion has significant role to change wetland into water area. As much $331 \mathrm{Ha}$ wetland area is already transformed into water body. Kesbanglinmas [2007] in their report stated that from $12.5 \mathrm{~km}$ coast length in Wedung sub district, $5.5 \mathrm{~km}$ of them is hit by wave erosion. In addition, ponds area which is affected by wave erosion is $175 \mathrm{Ha}$.

\section{Land Use Map 2014}

Land use map was constructed from existing land use map from BAPPEDA [2009] and land cover map in 2014. Anderson's classification is considered to define the classes and nomenclature. The result of this process is illustrated in Figure 4.

This research realizes that there is a little bit different of land cover and land use map in 2014 especially on settlement class. It happens because land cover map is assessed with the higher resolution satellite image such as Aster from Google Map; meanwhile land 


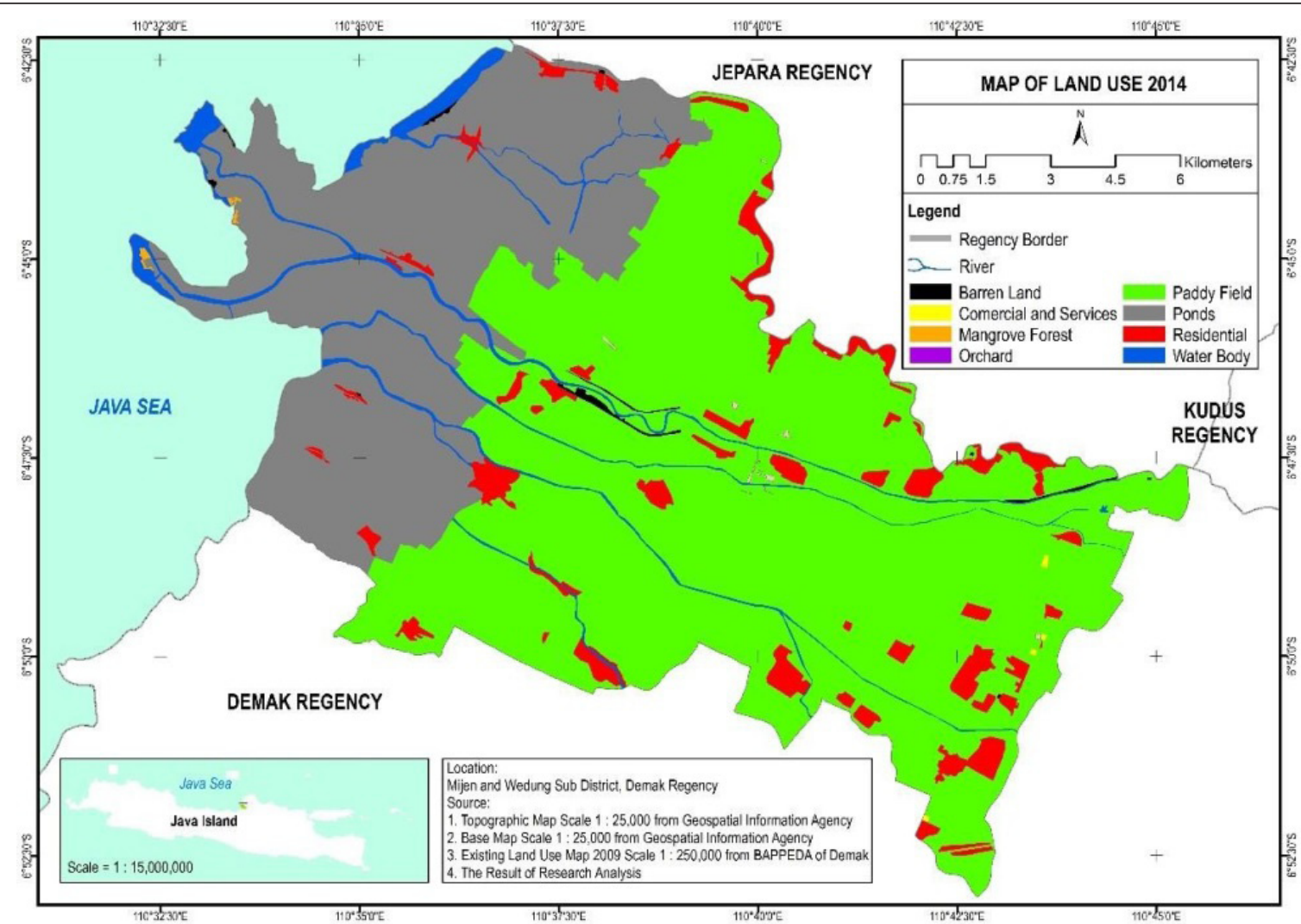

Figure 4. Land Use Map of Mijen and Wedung Sub District in 2014

use need more detail verification by ground truth. About 70 sample points was applied for land cover map verification and 124 sample points taken for ground truth of land use map of 2014. Overall, the location of each land use has no different with the land cover map of 2014.

The result shows that the biggest area of Mijen and Wedung sub district is paddy field $(9,017 \mathrm{Ha})$ followed by ponds with $4,524 \mathrm{Ha}$. The smallest area is commercial and services $(6 \mathrm{Ha})$ because in both sub district are lack of company or industry built there. Mangrove forest also limited with $9 \mathrm{Ha}$ only. The observation shows mangrove area only located in certain region near Java Sea especially at Berahan Wetan. Meanwhile along coast of Kedungkarang and Kedungmutih, there is limited mangrove plantation with spread individually.

\section{Accuracy Assessment of Land Use Classification}

From the calculation, the highest producer accuracy is ponds with $89.47 \%$ followed by paddy field $(89.36 \%)$ and residential $(76.19 \%)$. The accuracy value indicates that ponds are the highest probability of a reference site being correctly classified. The lowest accuracy is water body with $42.86 \%$ followed by mangrove forest and orchard both in the same value with $50 \%$.

Based on the user accuracy, residential becomes the most accurate reach to $84.21 \%$. Almost reach similar value is paddy field with exactly $84 \%$ accuracy. This value implies that pixel on the map is implied on the field. Meanwhile, the weakest user accuracy is mangrove forest (50\%). Mangrove forest is difficult area to be found in field because the area is very limited and most of the location is took place at outer research area. The result of overall accuracy assessment is $78.23 \%$. It implies that $78.23 \%$ of the classification result matches with the reference data.

\section{Flood Events}

From interview result and secondary data collection, Mijen and Wedung sub district was hit flood four times in period 2000-2014. In 2002, river flood happened in Kedungkarang, Tedunan, Kedung Mutih, Babalan, Kendal Asem, Mutih Wetan and Mutih Kulon. In January $24^{\text {th }}, 2006$, flood localized at Jleper, Ngelokulon, Pasir and some area in Ngegot villages. Riverine flooding in April 2013 striked Mijen sub district (Mijen, Pecuk, Jleper, Ngelokulon, Pasir, Ngegot and Legosari) and some village in Wedung sub district (Jungsemi, Mutih Wetan and Mutih Kulon). In early 2014, flood inundated all villages which are bordered directly with Jepara district (from Kedungkarang to Mijen village). The detail of flood inundation description is shown on the Figure 5, 6, 7 and 8. 


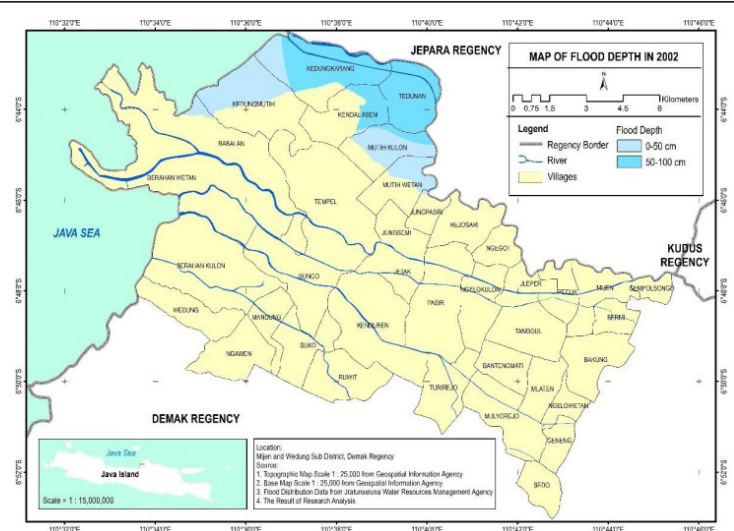

Figure 5. Map of Flood Depth in 2002

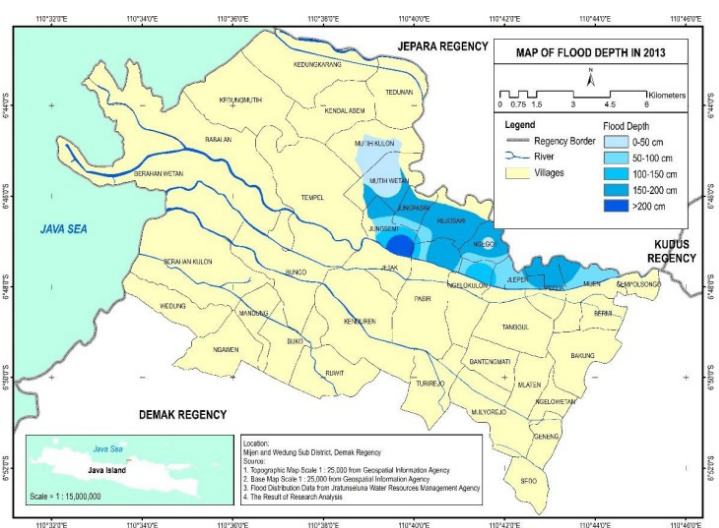

Figure 7. Map of Flood Depth in 2013

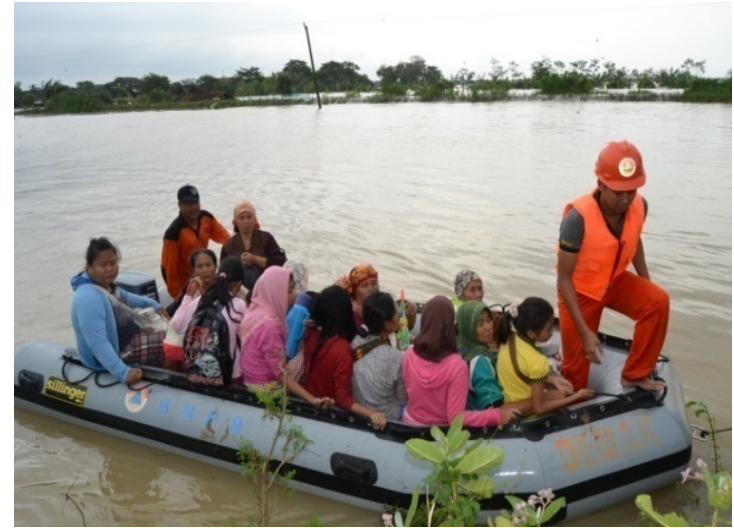

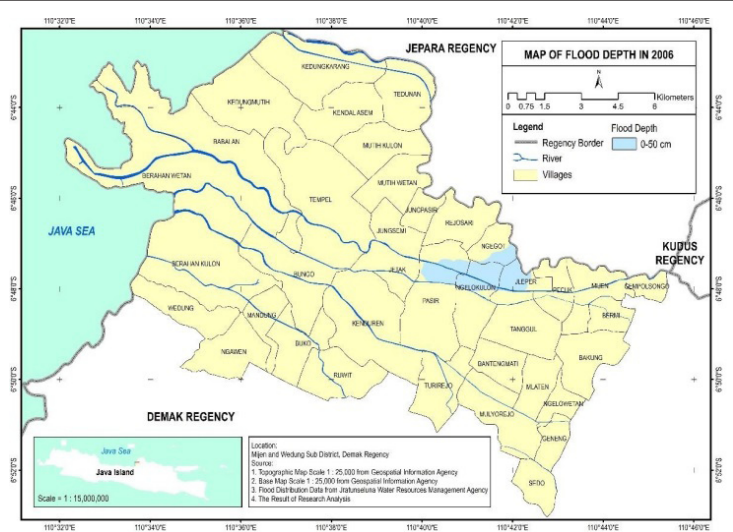

Figure 6. Map of Flood Depth in 2006

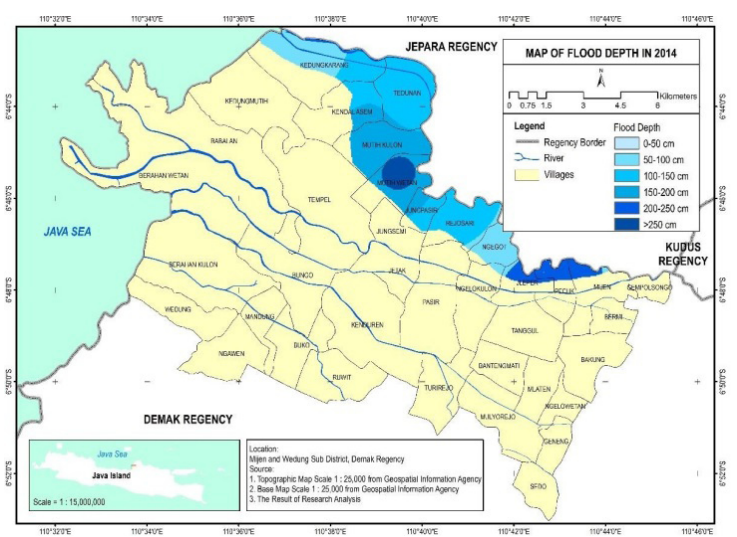

Figure 8. Map of Flood Depth in 2014

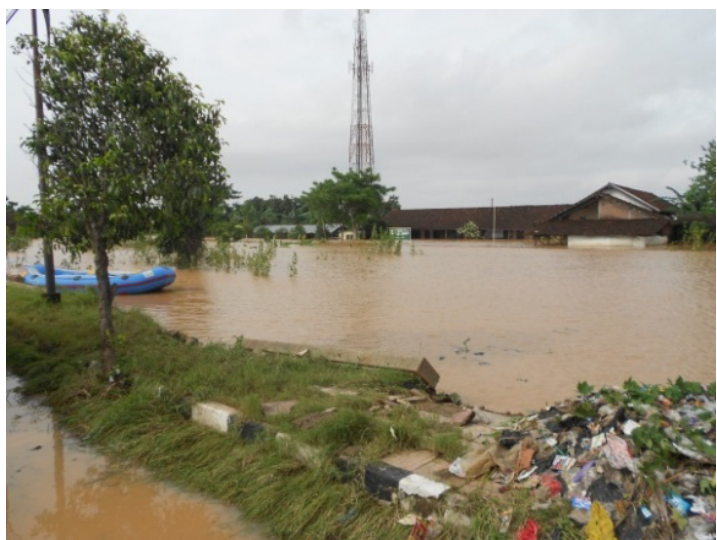

Figure 9. Flood 2004 hits Pecuk (right) and Mijen (left) village [BPBD, 2014].

Based on Damage and Losses Assessment Report by BPBD Demak Regency in 2014; in Mijen sub district, flood at January 2014 inundated permanent and semipermanent resident in Pecuk, Jleper and Ngegot village. In agricultural sector, this flood made damage on paddy field plantation in Mijen $113 \mathrm{Ha}$, Pecuk $26 \mathrm{Ha}$, Jleper $23 \mathrm{Ha}$, Ngelokulon $42 \mathrm{Ha}$, Pasir $74 \mathrm{Ha}$, Rejosari $51 \mathrm{Ha}$, Ngegot $8 \mathrm{Ha}$, Bermi $28 \mathrm{Ha}$ and Gempolsongo 21 Ha. Orchard plantation (including corn, sweet potato and red onion) around $38 \mathrm{Ha}$ which is separated in Mijen, Pecuk, Jleper, Bermi and Gempolsongo village were inundated too. The total losses in Mijen sub district was calculated about 7.3 billion rupiahs.
Meanwhile in Wedung sub district, semiresident permanent at Kendalasem, Kedungkarang, Mutih Kulon, Mutih Wetan and Tedunan village was inundated by flood. As much as $210 \mathrm{Ha}$ paddy field at Tedunan, Kendalasem (128 Ha), Mutih Kulon (300 $\mathrm{Ha}$ ), Mutih Wetan (403 Ha) and Jungpasir (229 Ha). In addition, ponds area (including salt, fish and shrimp) in Tedunan, Kedungkarang and Kendal Asem was affected by flood. The amount of damage and loses caused this disaster is 8.2 billion rupiahs.

Although Mijen and Wedung sub district located on relatively flat area, the depth of inundated area was various. The distribution of flood water depth is showed 
in the figure 9. The depth of flood in 2002 was not more than 1 meter whereas in 2006 became smaller to be less than $50 \mathrm{~cm}$. Flood event in 2013 reached until arround 2 meters. Flood event in 2014 was the biggest with the water depth reached more than 2.5 meters.

From the four flood events (2000, 2006, 2009 and 2014) data, it is known that flood disaster is influenced by the amount of rainfall. World Meteorological Organization (WMO) is classified the rainfall intensity into five groups. It is applied also by Meteorological and Geophysics Agency of Indonesia. The data rainfall data shows that Mijen and Wedung sub district classified as heavy-very heavy rainfall intensity. The high intensity of rainfall and water runoff from the upstream caused more pressure to the river body and outlet tunnels. After the river body cannot accommodate the water runoff, it collapses the dike and river banks. Tidal flow is another supporting factor of flood that can happen, flood 2002 in mention.

\section{Encroachment Area}

In purpose to get the trusting encroachment area indication, this research combined the result of visual interpretation analysis of Landsat images with interview and field observation result. The indication of encroachment activity was known by the result of land cover change analysis. The significant fall of mangrove forest and the double growth up of settlement can be indicator the probability of land encroachment activities.

Another indication is the development of riparian area. Based on President Regulation No. 38 Year 2011 about River, river corridor is one of river structures. River corridor has aimed as buffer zone between river and land ecosystem so the river function and human activity not be disturbed each other. As two of main rivers in the North Coast of Java, Wulan and Serang rivers has minimum 15 meters of corridor along right and left side of the river. The consequence is the development not allowed there. Unfortunately, this research found some development activities in river corridor.

Overall, the total encroachment area is about 8 Hectares (Ha). It shows that encroachment activity happened only in small scale at the research area. However, this encroachment activity became serious problem because most of them were occurred on river borders, mangrove and riparian area. The evidence strongly showed that most of mangrove forest transformed into ponds area. In addition, settlement development take place in river borders and riparian area especially Wulan and Serang river. The illustration showed on Figure 10.

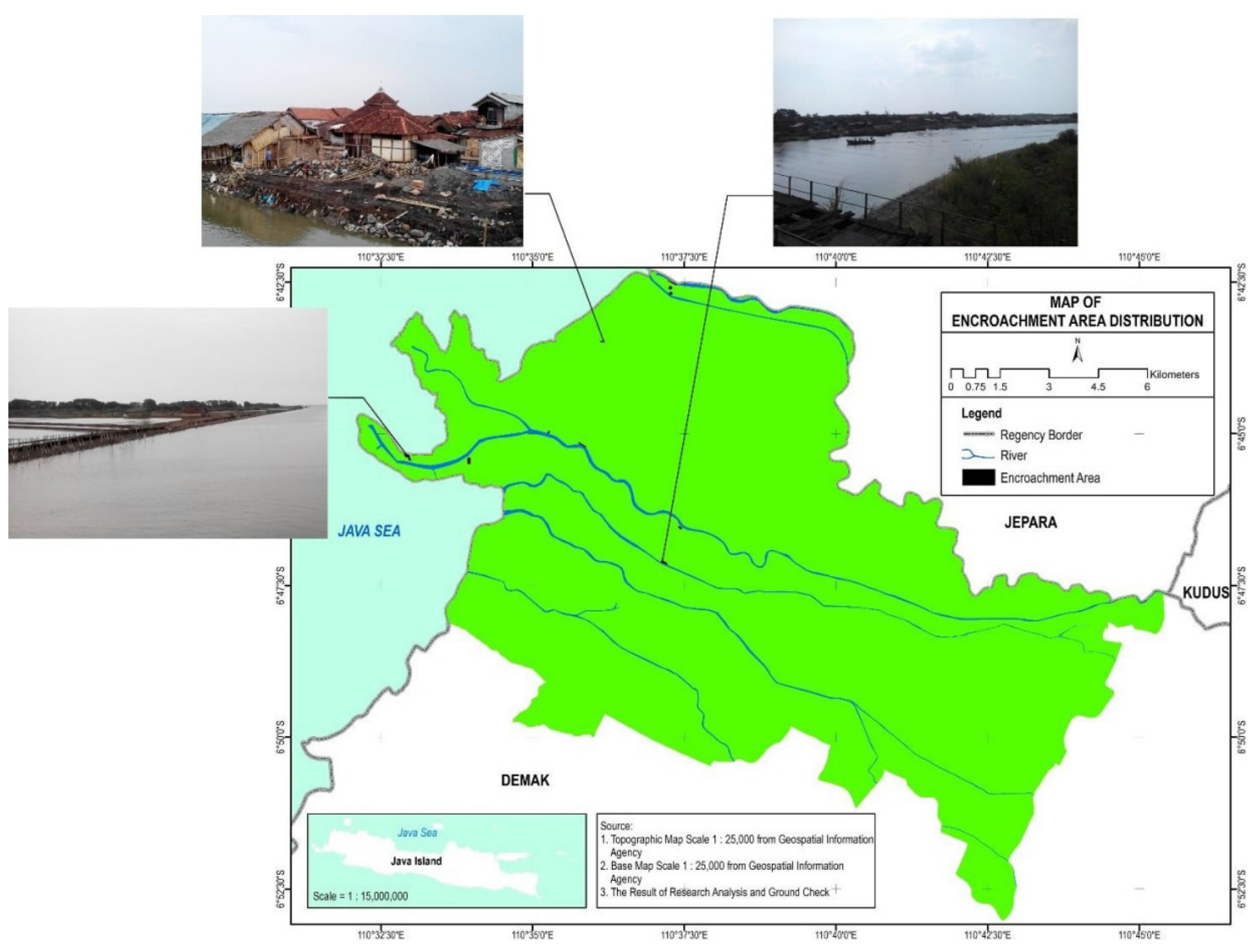

Figure 10. Map of Encroachment Area Distribution 
The right picture of previous map shows the existing of settlement along Wulan River at Babalan village. On the left, the picture describes the development of permanent and semi-permanent houses near canal at Kedung Mutih village. The rocks and sand already drop for the beginning of construction phase. The left picture of the map shows the ponds area. People expropriated the mangrove forest and changed it into ponds. The remaining mangrove forest is located in the north of Wulan River that abutted on sea.

Mangrove forest losses, illegal settlement and development at riparian area are the encroachment activity which reduce the river body and decrease the water catchment capacity. As a consequence, when the heavy rainfall happens, the river cannot accommodate the amount of water (overflow). This condition triggers the flood hazard become bigger each period.

\section{Cause Effect of Riverine Flooding}

A qualitative technique by using key informant interview is applied to identify the component and relation between them.

Descriptive analyze were used to analyze the data gathered from agency reports and interviews result.

\section{Driving Force and Pressure}

From the interview result, most of the key informants stated that high intensity of rain fall and the collapse of dikes is the main driver of flood. It is supported by informant statement.

"This disaster happened is caused the high intensity of rainfall, shallowness of river, and the fragile of soil structure. Human factor can be another cause too. Several people plant on the dike area with grass may be it can reduce the sturdiness of the dike." (Informant 8, Mijen Sub District)

"The rainfall is huge. Human factor also has important role in flooding. Undisciplined behavior, you can see in front, they build settlement in irrigation area. It should be not allowed." (Informant 7, Wedung Sub District).

State

State defines as the conditions of the environment. Conditions here mean the level of physical, biological, chemical phenomena in time and space (quality and or quantity). Demak regency (including Mijen and Wedung sub district) is the lowest part of Jratun-Seluna Watershed. Mijen and Wedung area is one of the final outlets of watercourse to Java Sea. This condition affects Mijen and Wedung sub districts as flood prone area especially caused by river flood and tide sea phenomenon. This probability will be higher if the rainfall intensity bigger too.
"Flood in 2002 happened caused by sent flood from the upper part. Meanwhile, high sea water occurred in the same time. So the overflow from the river detained by sea water and finally inundated most of coastal region in Wedung sub district including Babalan, Kedung Mutih, Kedung Karang, Tedunan, Kendalasem, Mutih Kulon and Mutih Wetan villages." (Informant 7, Wedung Sub District)

\section{Impact}

Mijen and Wedung flooding disaster especially in 2013 and 2014 resulted high economic loses. Based on the report [BPSDA, 2014], as much 6,400 houses are inundated by flood. In agricultural sector, most of paddy seedlings 15-25 days in north side of Wulan River are inundated. The total loses from 2013 flooding is 10 billion rupiah appraisal. It is supported by the informants.

"We already plant the seed around 15 days before and when the flood coming, we got nothing. We could not see the farm, even the seed because all inundated by flood." (Informant 4, Pecuk Village)

"In 2014, the flood inundated all region in Kedung Mutih where more east the area the flood became deeper. At the village office, the flood level was around $50 \mathrm{~cm}$, the other reach to 1.5 meter." (Informant 6, Kedung Mutih Village)

Generally, the impact of riverine flooding in Mijen and Wedung sub district divide into tangible and intangible loses. Tangible includes agricultural production, crops, income and residential damage; whereas intangible loses is psychological traumatic condition.

"People became traumatic after flood 2013." (Informant 1, BPBD)

Informant 8 (Mijen Sub District) said that:

"After flood disaster in 2013, some people felt trauma. It can be understood because it is the first big disaster in this region. Even when they stayed in refuge, they still asked and worry if the continuation flood would be happened."

\section{Response}

Based on interview result the response indicators consist of threetypes which are:

a. Technical Response

Technical response is applied by repairing and develop building which is can reduce or prevent the flood disaster. This response included rebuilds the dike and dredging the river sediment. 
"We made a report of flood disaster; we also proposed the repairing of Wulan river dike. There are 14 critical points in Wulan river dike." (Informant 8, Mijen Sub District)

\section{b. Local Knowledge Response}

This response came from society where they used their knowledge and natural resources there to solve the problem. Prop pillar building "anjang", paddy seed and other plantation selection became an example response from local people. It is important in aim to reduce the losses on agricultural sectors.

"After flood disaster, people make prop pillar 'anjang' to place the goods when the flood coming. Government also made Emergency Response Team (TRC 'Joko Tingkir') to prevent disater" Informant 8 (Mijen Sub District)

\section{c. Policy Response}

Several police was proposed to avoid flood disaster in future such as Emergency Response Team formation, disaster management training and hazard destruction assessment by BPBD of Demak Regency, proposal of watergate operation mechanism by Water Resources Management Agency etc.

"We have been preparing operational procedure disaster management. In 2015, we put down several budgeting account to provide equipment and infrastructure to prevent the disaster such as boat, life boat jacket, tent, kitchen set etc." (Informant 1, $B P B D)$

The detail list of DPSIR element and the indicator of flood are showed in the Figure 11.

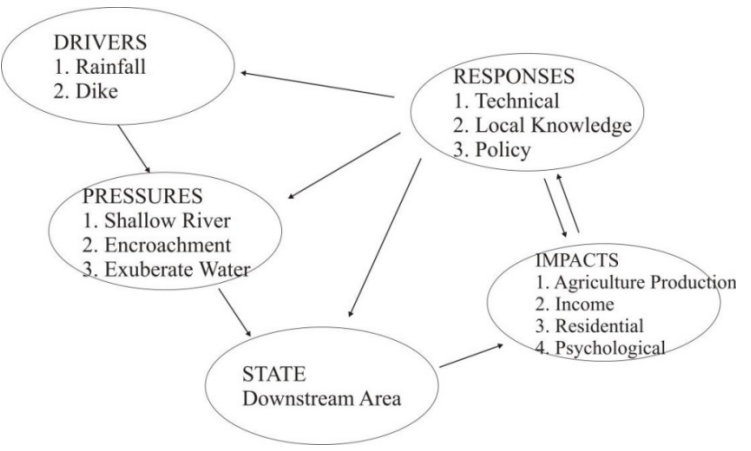

Figure 11. List of DPSIR Indicator of Flood in Mijen and Wedung Sub District (Source: Interview Result, 2014)

\section{The Relation among Land Use Change, Encroachment and Flood}

The analysis result shows that in downstream area (Mijen and Wedung sub districts), land use change does not directly influence the flood event. Most of flood events at Mijen and Wedung sub districts are caused by meteorological (high intensity of rainfall) and technical factor (collapse of the dike). WMO- GWP (2007) explain that rainfall include as meteorological factor contributing to flooding despite land use change and occupation of the flood plain as human factors. On the other side, land encroachment at Mijen and Wedung sub district has tendency contribute on development of flood hazard. The indication shows encroachment happened in research area especially at riparian ( river conservation) site. It was strength by interview result. Informant 3 (Farmer Association) stated that:

"A lot of illegal buildings are raised upper the dike. It happened without permission whereas the owner of that land is Public Worker Agency. Most of them are used for trade activity, for instance food stall and onion storehouse."

Mangrove forest losses, illegal settlement and development at riparian area reduce the river body and decrease the water catchment capacity. As a consequence, if the heavy rainfall happens, the river cannot accommodate the amount of water (overflow).

Meanwhile, this research also showed that flood influenced land use pattern in Mijen and Wedung sub districts. Built up areas including settlement, commercial and services are more developed in not flooded area as showed from the land use map where built up area in south area is more grow up than north area. The similar pattern also found in 2007, a resettlement program initiated by the government of Mozambique following a flood in Zambezi [Artur \& Hilhorst, 2014 ]. Flood also gave occasion to floodplain development decision more controllable in six urban areas of England and Wales [Parker, 1995 ].

\section{Conclusion}

Based on the result and analyzing, this research concludes that the main causes for riverine flooding in Mijen and Wedung sub district are meteorological (high intensity of rainfall) and technical factor (collapse of the dike). Area between Wulan and Serang rivers is the most affected by flood. On the other side, land encroachment at Mijen and Wedung sub district becomes one of pressure on riverine flooding. Most of the encroachment activity is happened at riparian area where it decreases the river bank capacity and increase flood disaster risk. 
Meanwhile the structural changes in 20002014 were happened in all level of land use classes. Land use change is not too affected the flood events but on contrary the flood influence land use pattern in north and south area of Mijen and Wedung sub districts. Flood influenced land use pattern in Mijen and Wedung sub districts. Built up areas (including: settlement, commercial and services) is developed much more in south prefer to north area. Interestingly, the interview result shows that majority of people in Mijen and Wedung sub district does less response in structural land use change because they believe it has less significant influence to their life.

Although flood hazard causes significant impact on agricultural production, income, residential and psychological traumatic condition; Mijen and Wedung resilience developed technical, local knowledge and policy response to face it. Moreover, cooperation reinforcement of every stakeholder there urges to do for better disaster management.

\section{Acknowledgment}

This article recieved grant of Insentif Penulisan Artikel Jurnal Internasional Berasal dari Tugas Akhir Mahasiswa in 2015. Therefore, acknowledgments are delivered to University of Gadjah Mada especially Badan Penerbit dan Publikasi UGM for the financial support during article writing period. The authors also wish to thank Dr. Estuning Tyas Wulan Mei, M.Sc. (Geography, UGM), who reviewed this article.

\section{References}

Agyemang, I., McDonald, A., \& Carver, S. (2007). Application of the DPSIR Framework to Environmental Degradation and Assessment in Northern Ghana. Natural Resources Forum, 31(3), 212-225.

Anderson, J. R., Hardy, E. E., Roach, J. T., Witmer, R. E., \& Peck, D. L. (1976). A Land Use And Land Cover Classification System For Use With Remote Sensor Data. A Revision of the Land Use Classification System as Presented in U.S. Geological Survey Circular 671, 964, 41.

Artur, L., \& Hilhorst, D. (2014). Land Use Policy Floods, resettlement and land access and use in the lower Zambezi , Mozambique. Land Use Policy, 36, 361-368. http://doi.org/10.1016/j. landusepol.2013.08.017

BAPPEDA. (2009). Revisi Rencana Tata Ruang Wilayah Kabupaten Demak Tahun 2010-2030. Demak. (in Bahasa Indonesia).

Benini, L., Bandini, V., Marazza, D., \& Contin, A. (2010). Assessment of land use changes through an indicator-based approach : A case study from the Lamone river basin in Northern Italy, 10, 4-14. http://doi.org/10.1016/j.ecolind.2009.03.016
BNPB. (2014). Data Kejadian Bencana Banjir. Retrieved July 30, 2014, from http://geospasial.bnpb.go.id/ pantauanbencana/data/databanjir.php.

Cao, Y., Zhou, W., Wang, J., \& Yuan, C. (2011). SpatialTemporal Pattern and Differences of Land Use Changes in The Three Gorges Reservoir Area of China During 1975-2005. Journal of Mountain Science, 8(4), 551-563. http://doi.org/10.1007/ s11629-011-2008-8.

Childs, C. (2004). Interpolating Surfaces in ArcGIS Spatial Analyst. ArcUser.

Ding, H., Wang, R.-C., Wu, J.-P., Zhou, B., Shi, Z., \& Ding, L.-X. (2007). Quantifying Land Use Change in Zhejiang Coastal Region, China Using MultiTemporal Landsat TM/ETM+ Images. Pedosphere, 17(6), 712-720. http://doi.org/10.1016/S10020160(07)60086-1.

El-Raey, M., Fouda, Y., \& Gal, P. (2000). GIS for Environmental Assessment of The Impacts of Urban Encroachment on Rosetta Region, Egypt. Environmental Monitoring and Assessment, 60(2), 217-233. http://doi.org/10.1023/ A:1006195006898.

Genxu, W., Yu, Z., Guimin, L., \& Lin, C. (2006). Impact of land-use change on hydrological processes in the Maying River basin , China, 49(10), 10981110. http://doi.org/10.1007/s11430-006-1098-6

Greene, R. P., \& Harlin, J. M. (1995). Threat to High Market Value Agricultural Lands from Urban Encroachment: A National and Regional Perspecitve. The Social Science Journal, 32(2), 137-155. http://doi.org/10.1016/03623319(95)90002-0.

Guo, L., Wang, D., Qiu, J., Wang, L., \& Liu, Y. (2009). Spatio-Temporal Patterns of Land Use Change Along the Bohai Rim in China During 1985-2005. Journal of Geographical Sciences, 19(5), 568-576. http://doi.org/10.1007/s11442-009-0568-0.

Gupta, S., \& Roy, M. (2012). Land Use / Land Cover classification of an urban area- A case study of Burdwan Municipality, India, 2(4), 1014-1026.

Kagalou, I., Leonardos, I., Anastasiadou, C., \& Neofytou, C. (2012). The DPSIR Approach for an Integrated River Management Framework. A Preliminary Application on a Mediterranean Site (Kalamas River -NW Greece). Water Resources Management, 26(6), 1677-1692. http://doi. org/10.1007/s11269-012-9980-9.

Kesbanglinmas (Ed.). (2007). Laporan Akhir Penelitian Penanganan Bencana Alam di Daerah Rawan BencanadiKabupaten Demak. Demak: Pemerintah Kabupaten Demak. (in Bahasa Indonesia).

Liu, J., Wang, S., \& Li, D. (2014). The Analysis of the Impact of Land-Use Changes on Flood Exposure of Wuhan in Yangtze River Basin, China, (28), 
2507-2522. http://doi.org/10.1007/s11269-0140623-1.

Mustopa, Z. (2011). Analisis Faktor-faktor yang Mempengaruhi Alih Fungsi Lahan Pertanian di Kabupaten Demak. Diponegoro University. Retrievedfromhttp://eprints.undip.ac.id/29151/1/ Skripsi015.pdf. (in Bahasa Indonesia).

Parker, D. J. (1995). Floodplain development policy in England and Wales. Applied Geography, 15(4), 341-363. http://doi.org/10.1016/01436228(95)00016-W

Pirrone, N., Trombino, G., Cinnirella, S., Algieri, a., Bendoricchio, G., \& Palmeri, L. (2005). The Driver-Pressure-State-Impact-Response (DPSIR) approach for integrated catchment-coastal zone management: Preliminary application to the Po catchment-Adriatic Sea coastal zone system. Regional Environmental Change, 5(2-3), 111-137. http://doi.org/10.1007/s10113-004-0092-9.

Rachmawati, R., \& Budiarti, C. V. (2016). Use of Space and the Need for Planning in the Disaster-Prone Area of Code River, Yogyakarta, Indonesia. Indonesian Journal of Geography, 48(2), 178-190. http://doi.org/10.22146/ijg.17633.

Richards, J. A., \& Jia, X. (2006). Remote Sensing Digital Image Analysis (4th ed.). Springer-Verlag Berlin Heidelberg.

Shalaby, A., \& Tateishi, R. (2007). Remote sensing and GIS for mapping and monitoring land cover and land-use changes in the Northwestern coastal zone of Egypt. Applied Geography, 27(1), 28-41. http://doi.org/10.1016/j.apgeog.2006.09.004

WMO-GWP. (2007). The Role of Land-Use Planning in Flood Management - A Tool for Integrated Flood Management. WMO/GWP Associated Programme on Flood Management. 